\title{
Wage Losses and Inequality in Developing Countries: labor market and distributional consequences of Covid-19 in Turkey
}

\author{
Anil Duman \\ Central European University \\ dumana@ceu.edu
}

\begin{abstract}
We develop a possibility to work index (PWI) taking the ability to work from home and workplace closures into account. By using the data from the HLFS in Turkey, we examine the individual level determinants of PWI. Our findings reveal that PWI and ability to work from home are significantly different, and essential or closed jobs are not necessarily concentrated at the bottom of the wage distribution. Therefore, from a policy perspective, PWI can be a more encompassing measure of risk and can assist the public authorities to design better targeted social policies. Our results also point out that wage inequality is likely to deteriorate as a result of the supply shocks from confinement policies. However, the overall negative distributional effects of lockdown and disparity between employees in different economic activities become more substantial with duration. These suggest that in order to avoid major increases in earning inequalities and related social problems, governments would be better off with shorter and stricter lockdowns.
\end{abstract}

JEL classification: D33, E24, J21, J31

Keywords: workplace closures, wage loss, wage inequality; teleworking; developing countries 


\section{Introduction}

The lack of medical treatment and vaccine for Covid-19 compelled many governments around the world to implement "stay at home" and social distancing policies at different scales and length. More than 114 countries, so far, have required partial or full closure of all but essential workplaces (Bsg.ox.ac.uk, 2020). These policies are expected to have substantial impact on the economy through production and demand shocks. As discussed by several studies, labor market consequences of social distancing highly depend on teleworking and to what extent tasks of a job can be undertaken at home (Dingel and Neiman, 2020; Gottlieb et al., 2020). Nevertheless, there are additional factors at the sectoral level that shape people's possibility to work during lockdown and confinement measures. Even the most stringent government responses to Covid-19 affirmed particular economic activities, such as healthcare, food, energy and telecommunications as essential while closing others such as sports, entertainment, restaurants and tourism to limit the spread of the virus (del Rio-Chanona et al., 2020; Barrot et al., 2020). Hence, essential workers, regardless of their ability to work from home, have been much less affected from the supply shocks and managed to keep their earnings as opposed to employees in closed economic activities who have faced significant losses independent of their teleworkability.

Our first goal in this paper is to develop a possibility to work index (PWI) taking the sectoral differences into account as well as the ability to work from home. While there are few studies adopting a similar strategy, these almost exclusively focus on developed countries that have notably higher teleworkability and government policies. Hence, we aim to extend the growing literature on labor market risks of social distancing and lockdown by utilizing the case of a 
developing country, Turkey, which has comparable labor market structure and confinement measures to a number of other middle-income economies ${ }^{1}$. The second objective of the paper is to examine the distributional consequences of lockdowns and workplace closures. Labor market risks are unevenly spread across workers, which imply that the negative effects of confinement policies would be felt disproportionately by particular groups. If the individuals who are less able to work during the pandemic are also vulnerable workers, social distancing is expected to generate higher inequalities. While such an overlap is apparent for teleworking, the intersection is less clear cut for employees in closed and essential economic activities. Hence, distributional consequences of lockdown are contingent on the shares of employment in each category of work and the associated wage levels.

We found that the individual level determinants of PWI are significantly different than ability to work from home, and closed jobs are not necessarily concentrated at the bottom of the wage distribution. Therefore, from a policy perspective, PWI can be a more encompassing measure of risk and can assist the public authorities to design better targeted social policies. Moreover, PWI can be helpful to recognize which jobs generate larger wage losses because of workplace closures, and these jobs can be excluded from future lockdowns by taking the necessary health precautions instead whenever feasible. Our results also point out that wage inequality is likely to deteriorate as a result of the supply shocks from confinement policies. However, the overall negative distributional effects of lockdown and disparity between employees in different economic activities become more substantial with duration. These suggest that in order to avoid major increases in earning inequalities and related social problems, governments would be better off with shorter and stricter lockdowns.

\footnotetext{
${ }^{1}$ Table A1 and A2 in the Appendix present the share of teleworkable jobs, stringency of workplace closures and sectoral employment shares of Turkey and few selected economies at similar GDP per capita.
} 
In the next section, we provide a brief review of the literature focusing on the impacts of Covid-19 on labor markets. The third section of the article presents data utilized to construct PWI, econometric techniques and inequality measures. In the fourth section we show our empirical findings and discuss their policy implications. The final section briefly summarizes the arguments of the paper and highlights its limitations.

\section{Brief Review of Covid-19 and Labor Markets}

One of the most widely explored aspects of the relationship between the pandemic and the labor markets is the ability to work from home. Because of lockdowns and other social distancing measures implemented in numerous countries, many jobs have been fully or partially conducted at home. However, there are important distinctions with regards to teleworking across occupations, countries and worker groups. For example, it has been shown that almost $34 \%$ of the US jobs and between 24-31\% of the EU jobs can be performed at home (Dingel and Neiman, 2020; Boeri et al., 2020). These ratios get much smaller for developing countries ranging from $5.5 \%$ in Ghana to $23 \%$ in China (Saltiel, 2020). In less developed countries workers have fewer opportunities to work from home due to technological limitations as well as the industrial composition. For example, amenability of homeworking is decreased with the level of development since agricultural and other low productivity jobs are not possible to perform from home (Gottlieb et al., 2020; Hatayama et al., 2020). Hence, developing economies differ significantly from the advanced countries both in terms of the availability of occupations that can be teleworked and number of people employed in such jobs. Nevertheless, it has also been found that highly educated, well-paid and less vulnerable workers are typically concentrated in 
teleworkable jobs in developing and developed world (Delaporte and Rena, 2020; Hatayama et al., 2020).

We contribute to the above mentioned literature by analyzing the case of Turkey and including the industrial status as well as teleworking for measuring the possibility to work during the pandemic. In addition to working from home, social distancing and lockdown policies also caused particular economic activities to be shut down temporarily. Governments such as Italy, Spain, Argentina and India implemented strict restrictions and closed down many activities that were not deemed as essential (Bsg.ox.ac.uk, 2020). Besides, other social distancing measures including number of people allowed in confined spaces, travel limitations and curfews led many industries such as hospitality and travel, to close down even when there were no explicit workplace closures. Lockdown and de facto reductions in the operations of these economic activities versus essential jobs mean extra risks for the employees of the former. To our knowledge, there are only three studies looking at the industrial distinction as well as teleworking capacity of occupations. In the US, $44 \%$ of the employees are in essential jobs and for these workers; ability to perform tasks from home doesn't make a difference from the supply side. In contrast, among the non-essential workers, $21 \%$ are in non-essential jobs, and remote work became a significant determinant of their labor market risks after the pandemic (del RioChanona et al., 2000). For EU countries, $25 \%$ of the employment is in essential activities while nearly $10 \%$ of the workers are in jobs that were shutdown (Perez et al., 2020). Moreover, the relationship between averages wages and ability to work disappear when essential and closed sectors are added to the picture (Palomino et al., 2020).

Given that numerous economic activities are affected from social distancing and lockdown, it is also very likely that the pandemic would have significant distributional implications. For 
example, it is found that less educated and younger workers from ethnic minorities experienced larger job and earnings losses after the start of the pandemic (Cho and Winters, 2020; Montenovo et al., 2020). While the negative effects can be partly explained by pre-pandemic occupational sorting, the necessity of interpersonal contact at the job also gained importance. Besides, the uneven allocation of teleworking among workers and the related wage losses, it is usually argued that social distancing produces larger inequalities in the labor markets (Palomino et al., 2020; Brunori et al., 2020). On the one hand, there are high educated and well-paid employees who continue to hold their jobs, and on the other hand, there are vulnerable workers facing additional risks due their inability to work from home. Nonetheless, there is no clear association between the distribution of essential and closed jobs under lockdown and individual characteristics or average wages (Perez et al., 2020; Palomino et al., 2020). Thus, changes in wage inequality due to the supply shocks brought by Covid-19 depend on the ability of individuals to continue to work both in terms of teleworking and being employed in essential or closed economic activities. We add to these studies by analyzing the changes in wage inequality under different lockdown scenarios in Turkey, by looking at the wage losses as a function of possibility to work.

\section{Data and Methodology}

\subsection{Construction of Possibility of Work Index}

In order to measure the possibility of work during the lockdown, we first divide the economic activities into three categories; essential, closed and non-essential and not closed, in other words 
teleworkable. In order to distinguish the essential and closed economic activities, we use the official decrees beginning on the $11^{\text {th }}$ of March, which correspond to the date of coronavirus being declared as a pandemic by World Health Organization (WHO). Since then Turkish government has been implementing a relatively moderate lockdown ${ }^{2}$, and started to lift a number of restrictions as of May $11^{\text {th }}$. In essential sectors, individuals are able to carry on their jobs as usual $^{3}$ even during the pandemic whereas in closed sectors, the opposite is true as these jobs become impossible to undertake either due to de jure or de facto measures. Hence, for neither of these categories working from home is relevant. For the sectors that are neither essential nor closed, teleworkability is central since individuals can continue their tasks as long as they are able to work from home. In sum, our possibility of work index (PWI) is as follows:

$$
P W I_{i}=\left\{\begin{array}{c}
1 \text { if } i=E \\
T_{o} \text { if } i=N E \text { or } N C \\
0 \text { if } i=C
\end{array}\right\}
$$

Essential and closed economic activities are coded at NACE (Rev.2) 2-digit level, according to the changes in the legislation that are published in the Official Gazette and circulars of Ministry of Interior. Table A3 in the Appendix provides the codes at the detail level. Teleworkability index, $T_{o}$, is estimated at the ISCO-08 2-digit level, based on the classification

\footnotetext{
${ }^{2}$ The Government Response Stringency Index of Turkey is around 75, a composite measure based on nine response indicators including school closures, workplace closures, and travel bans, rescaled to a value from 0 to 100 (100 is the strictest response). For details see, https://ourworldindata.org/grapher/covid-stringencyindex? tab $=$ chart\&country $=\sim$ TUR

${ }^{3}$ Certainly, there are sizable health risks for such employees as they are more exposed to the virus and have lower possibility of avoiding contagion. For example, in the UK, it has been found that among the essential workers, security guards have a much higher mortality rate than the other occupational categories. For details, see https://www.ons.gov.uk/peoplepopulationandcommunity/healthandsocialcare/causesofdeath/bulletins/coronavirusco vid19relateddeathsbyoccupationenglandandwales/deathsregisteredbetween9marchand25may2020
} 
developed by Dingel and Neiman $(2020)^{4}$. They assign teleworkable scores to 6-digit O*NETSOC occupations by employing various responses on the nature of occupation and its task composition. The index ranges between 0 and 1 suggesting the proportion of job that can be performed from home. 6-digit O*NET-SOC occupational scores are transformed into ISCO-08 2-digit by the ILO crosswalk and taking into the relative weighting of related occupations.

Due to the differences in economic structure, technology and labor productivity, it is claimed that the US-based teleworkability index is not suitable for developing countries (Gottlieb et al, 2020; Saltiel, 2020). To overcome these shortcomings we also include the working from home measure constructed by Saltiel (2020) for robustness checks. According to this measure a worker is not able to work from home if either of the following tasks is performed at work: not using a computer, lifting anything heavier than 50 pounds, repairing/maintaining electronic equipment, operating heavy machinery or industrial equipment, or reporting that contact with customers is very important. Since Turkey is not included in the survey, we employ the weighted mean share at ISCO-08 2-digit level of 11 developing countries that are part of the STEP database 5 .

The main data source for the individual level estimations is Household Labor Force Survey (HLFS) collected by the Turkish Statistical Institute for the year of 2019. Overall, we have 385,166 observations covering a long list of demographic, industrial and occupational and contractual variables. As we discussed earlier, being employed in essential or closed economic activities are as important as being able to work from home during the lockdown. Table 1 describes the shares of different categories of employees and overall employment by economic activities. It can be seen that nearly $62 \%$ of the jobs in Turkey are in neither essential nor closed

\footnotetext{
${ }_{5}^{4}$ Major group 10, Armed Forces Occupations, is excluded from the estimations due to lack of data.

${ }^{5}$ It has to be noted that mean teleworkability scores according to both measures are quite similar for Turkey, around 0.25 by Dingel and Neiman's index and 0.24 according to STEP database.
} 
sectors while approximately $8 \%$ of people are employed in closed sectors suggesting that they experience considerable wage losses. On the other hand, almost $31 \%$ of the workers are in essential jobs, which could mean that their economic risks due to pandemic are minimal. Within the teleworkable workers, the share of university graduates and public sector employees are much higher than the rest. In contrast, informality, small firms, temporary contracts and younger cohorts are less frequent among the teleworkable jobs. However, unlike teleworkable jobs, there are no discernable individual and firm level characteristics that situate workers in essential or closed sectors. Thus, in the next section we use regression techniques to identify the determinants of PWI at the individual level.

Table 1. Share of Different Categories of Employees (\%)

\begin{tabular}{lccc}
\hline & Closed & Essential & Teleworkable \\
\hline Employment & & & \\
Youth (15-24 years old) & 22.05 & 30.08 & 61.77 \\
Female & 27.5 & 43.57 & 11.04 \\
University & 14.74 & 9.83 & 27.22 \\
No experience <1 year) & 28.39 & 9.55 & 28.24 \\
Small firm (<10 employees) & 66.44 & 87.03 & 19.38 \\
Informal & 36.52 & 78.74 & 47.13 \\
Temporary & 16.0 & 20.3 & 23.66 \\
Full-time & 92.1 & 80.03 & 11.2 \\
Public sector & 3.04 & 8.51 & 92.85 \\
\hline Source: Author's calculations & & 21.51 \\
\hline
\end{tabular}

Source: Author's calculations based on LFS (2019) 


\subsection{Empirical Strategy}

To understand the individual level factors that affect PWI, we employ zero-one inflated beta regression model, which are developed to analyze continuous dependent variables that fall within a 0 to 1 interval and where zero and one outcomes might be subject to different processes than the medium range (Ospina and Ferrari, 2012). This is exactly the case with PWI since being in an essential or closed sector depends on the governmental decrees while teleworkability is determined by the extent of the tasks that can be done from home. PWI has values between 0 and 1, and additionally the high share of zeros and ones can cause bias in the estimations. From Figure A1 in the Appendix, it can be seen that almost $23 \%$ of PWI has a value of 0 and more than $32 \%$ of PWI has a value of 1 . Inflated beta regression takes this into account and allows complete modeling of the entire continuous interval from zero to one by combining the inflated densities:

$$
f=\left(y ; \pi_{0}, \pi_{1}, \mu, \varphi\right)=\left\{\begin{array}{c}
\pi_{0} \text { if } y=0 \\
\left(1-\pi_{0}\right)\left(1-\pi_{1}\right) f(y ; \mu, \varphi) \text { if } 0<y<1 \\
\pi_{1} \text { if } y=1
\end{array}\right\}
$$

From the above density function we can build our regression model where PWI is the zeroone inflated dependent variable. In terms of individual level examinations, we include demographic and personal variables (Youth, gender, education and no experience), job and sectoral variables (small, informal sector, contract type, part-time work and public sector). Youth is a dummy variable for the ages between 15-24 years old, small firm is a dummy variable representing companies having less than 10 employees and no experience is working less than 1 
year. These variables are selected, first of all, because they can affect the labor market risks significantly. Moreover, the existing studies largely rely on similar variables, which make our findings easier to compare. We also involve regional dummies at NUTS-1 level in the proportional beta part of the regression but not for zero and one logistics regressions since the governmental regulations are implemented at the national level. All three processes, being in essential or closed or teleworkable job, are regressed simultaneously using a logistic regression for zeros and ones and a beta regression for the interval values ${ }^{6}$. The regression equation is:

$P W I_{i}=\left\{\begin{array}{c}\operatorname{pr}\left(\beta_{i} X_{i}+\beta_{i} \text { Region }\right) \text { if } 0<P W I<1 \\ \text { logit }\left(\beta_{i} X_{i}\right) \text { if } P W I=0 \\ \operatorname{logit}\left(\beta_{i} X_{i}\right) \text { if } P W I=1\end{array}\right\}$

\subsection{Wage Losses and Inequality}

The next part of our analysis considers the distributional effects of social distancing and lockdown policies. We argue that PWI is inversely related to wage losses; hence a worker in an essential job can receive the same earnings despite the pandemic. On the contrary, people employed in closed sectors have to face full wage losses for the duration of the lockdown in the absence of social policy. For individuals in neither essential nor closed sectors, their wage loss risk is inversely proportional to their ability to work from home. Additionally, we consider three scenarios; 1 month of lockdown, 3 months of lockdown with previously closed economic activities operating at 50\% capacity, and 6 months of lockdown with previously closed economic activities operating at $90 \%$ capacity. The last two scenarios aim to represent the situations where

\footnotetext{
${ }^{6}$ We utilized zoib package in Stata15 to run the zero-one inflated beta regressions. For details of the technique, see Ospina and Ferrari (2012).
} 
social distancing and regulations force particular sectors to alter their operations, for example, the space requirements and quotas on number of people that can be accepted in restaurants, bars, sporting activities. Also, the governments might reintroduce some of the containment measures while relaxing others, which might delay the full recovery of the closed sectors. In view of that, the new yearly wage function in each category of economic activity under different scenarios is as follows:

$Y W_{i t}=\left\{\begin{array}{c}{\left[12 * W_{\text {it }-1}\right] \text { if } i=E} \\ {\left[(12-L) * W_{i t-1}+\left(L * W_{i t-1} * P W I\right)\right] \text { if } i=N E \text { or } N C} \\ 0 \text { if } i=C\end{array}\right\}$

where $\mathrm{L}$ is the duration of lockdown and $\mathrm{W}$ is the net monthly wage. For 3 months and 6 months lockdowns, $50 \%$ and $10 \%$ of the previously closed economic activities remain closed in that order.

In the final step of our estimations utilize four different inequality measures to understand how lockdown affects the wage distribution in the Turkish labor market. First, we look at the Gini coefficients and Generalized Entropy Index (GE) with different parameter values for weighting using the wage information obtained from LFS in the absence of social distancing. We consider two special cases, where $\alpha$ takes a value of 0 , making the GE index especially sensitive to the existence of low wages and a value of 1 denoting the sensitivity to high incomes. Then, we calculate the same coefficients for each scenario using the yearly wages from equation (4). Lastly, we decompose wage inequality by the categories of PWI to identify how much of the change in inequality can be attributed to the changes in the distribution of wages in essential, closed and teleworkable jobs as well as between jobs. The additive nature of GE indices enables 
us to compute the distributional statistics for subgroups (Foster and Shneyerov, 2000). We can obtain the within and between group inequality from the following equation:

$G E_{\alpha}=\sum_{k=1}^{m}\left(\frac{\overline{y_{k}}}{\bar{y}}\right)^{\alpha}\left(\frac{n_{k}}{n}\right)^{1-\alpha} G E(\alpha)_{i}+\frac{1}{\left(\alpha^{2}-\alpha\right)}\left\lfloor\sum_{k=1}^{m} \frac{n_{k}}{n}\left(\frac{\overline{y_{k}}}{\bar{y}}\right)^{\alpha}-1\right\rfloor$

where $G E(\alpha)_{i}$ is the GE index of the $\mathrm{i}^{\text {th }}$ subgroup. The first term on the right hand side is the within component of inequality based on the weighted average of GE indices for each group. The second term shows the between component using the subgroup mean incomes, $\overline{y_{k}}$.

\section{Findings and Discussion}

\subsection{Individual Level Determinants of PWI}

Based on our zero-one inflated beta regressions we display the individual level determinants of PWI in Table 2 to inspect whether there are particular groups that are subject to higher risks due to lockdown. Telework scores are positively related to university education, experience, formal and public sector employment, permanent contracts, larger firms and full-time positions. Hence, it can be argued that the more advantaged workers in the Turkish labor market also have higher ability to work from home, which shields them against specific risks during lockdown. These findings are mostly in line with other studies examining the characteristics that lead to higher teleworkability. It is affirmed that women, university educated and formal sector workers are more likely to have higher ability to work from home (Hatayama, 2020; Delaporte and Pena., 
2020; Saltiel. 2020). Since occupational sorting before the pandemic depends heavily on these individual features, it is also found that less educated and younger workers faced greater employment losses (Cho and Winters, 2020; Montenovo et al., 2020). Our results on teleworking also confirm that less educated, younger and inexperienced employees and informal sector workers have lower ability to work from home, which significantly reduce their capacity to handle the economic difficulties of the pandemic.

Nevertheless, it should be noted that, the sign and magnitude of the coefficients for individual level covariates are highly different across three categories. For example, youth and informality reduce the ability to work from home but increases the likelihood of both being employed in an essential or closed sector. Hence, the risk of wage loss for younger and informal workers is not straightforward as they have lower chances of working from home but have higher possibility of holding an essential job. In fact, all the covariates in our estimations, with the exception of university education and public sector employment, have ambiguous impact on PWI and subsequently on wage losses. The macro-level analyses for the US and EU that look at demand and supply shocks also highlight that workers in non-essential and non-teleworkable jobs are subject to the greatest unemployment and wage loss risks (del Rio-Chanona et al., 2020; Barrot et al., 2020). Our estimations add to this literature by expanding the case to Turkey and by treating essential and closed sectors as special cases of working ability during the pandemic. For robustness checks, we estimated the impact of the same covariates on being employed in essential, closed and teleworkable jobs by separate logistics regressions. The results are available in Table A3 in the Appendix. All the coefficients have the same signs and comparable magnitudes ${ }^{7}$ but the standard errors are larger when the distributional problems are overlooked.

\footnotetext{
${ }^{7}$ The only exception is temporary contracts for teleworking, which is statistically insignificant when the economic activities are regressed individually.
} 
Table 2. Estimation Results for Possibility of Work

\begin{tabular}{|c|c|c|c|c|c|c|}
\hline & PWI=Telework & & PWI=Essential & & PWI=Closed & \\
\hline & Coefficient & $\overline{\mathrm{SE}}$ & Coefficient & $\mathrm{SE}$ & Coefficient & $\mathrm{SE}$ \\
\hline Youth & $-0.05^{* *}$ & 0.01 & $0.21 * *$ & 0.03 & $0.42 * *$ & 0.02 \\
\hline Female & $0.40 * *$ & 0.01 & $0.85^{* *}$ & 0.02 & $0.12 * *$ & 0.02 \\
\hline University & $0.45 * *$ & 0.01 & $0.22 * *$ & 0.02 & $-0.37 * *$ & 0.02 \\
\hline No experience & $-0.19 * *$ & 0.01 & $-0.12 * *$ & 0.03 & $-0.10 * *$ & 0.02 \\
\hline Small firm & $-0.04 * *$ & 0.01 & $-0.28 * *$ & 0.03 & $-0.26 * *$ & 0.02 \\
\hline Informal & $-0.13 * *$ & 0.01 & $1.10 * *$ & 0.03 & $0.38 * *$ & 0.02 \\
\hline Temporary & $-0.04 * *$ & 0.01 & $0.63 * *$ & 0.03 & $-0.24 * *$ & 0.03 \\
\hline Full-time & $0.29 * *$ & 0.02 & $-0.30 * *$ & 0.04 & 0.00 & 0.04 \\
\hline Public sector & $0.73 * *$ & 0.01 & $0.86^{* *}$ & 0.03 & $-1.44 * *$ & 0.03 \\
\hline Region & Yes & & No & & No & \\
\hline Constant & $-0.77 * *$ & 0.01 & $-2.47 * *$ & 0.02 & $-0.66 * *$ & 0.01 \\
\hline Number of obs & 104,097 & & 104,097 & & 104,097 & \\
\hline Wald chi2(26) & 16241.39 & & 16241.39 & & 16241.39 & \\
\hline Prob > chi2 & 0.00 & & 0.00 & & 0.00 & \\
\hline
\end{tabular}

Notes: The model is estimated using zero-one inflated beta regression with robust standard errors. $* *$ and $*$ denote statistical significance at the .01 and .05 levels, respectively.

In Figure 1, we present the marginal effects of individual level variables across three predicted outcomes; teleworkable, essential and closed jobs. Once again, it is visible that covariates' impacts on the outcomes differ significantly across job categories. For example, the likelihood of an informal worker in Turkey to be in an essential job is 14 points higher than a formal sector worker, which is mainly due to the inclusion of agricultural production and various other low-pay occupations. However, informality also reduces the ability to work from home by 7 points and increase the likelihood of having a closed job by 3 points in comparison to the formal sector. These indicate that the wage losses as a result of pandemic related lockdown are unclear for informal sector workers. On the one hand, they can maintain their activities and 
earnings given their higher probability of being employed in essential jobs. On the other hand, they are subject to greater risks of wage loss because of lower ability to work from home and larger possibility of ending up in a closed economic activity. Similar conclusions can be derived for the other individual level factors too, and as mentioned above, only public sector employment and university education have unambiguous effects on PWI and the associated wage losses.

Figure 1. Marginal Effects of Individual Covariates

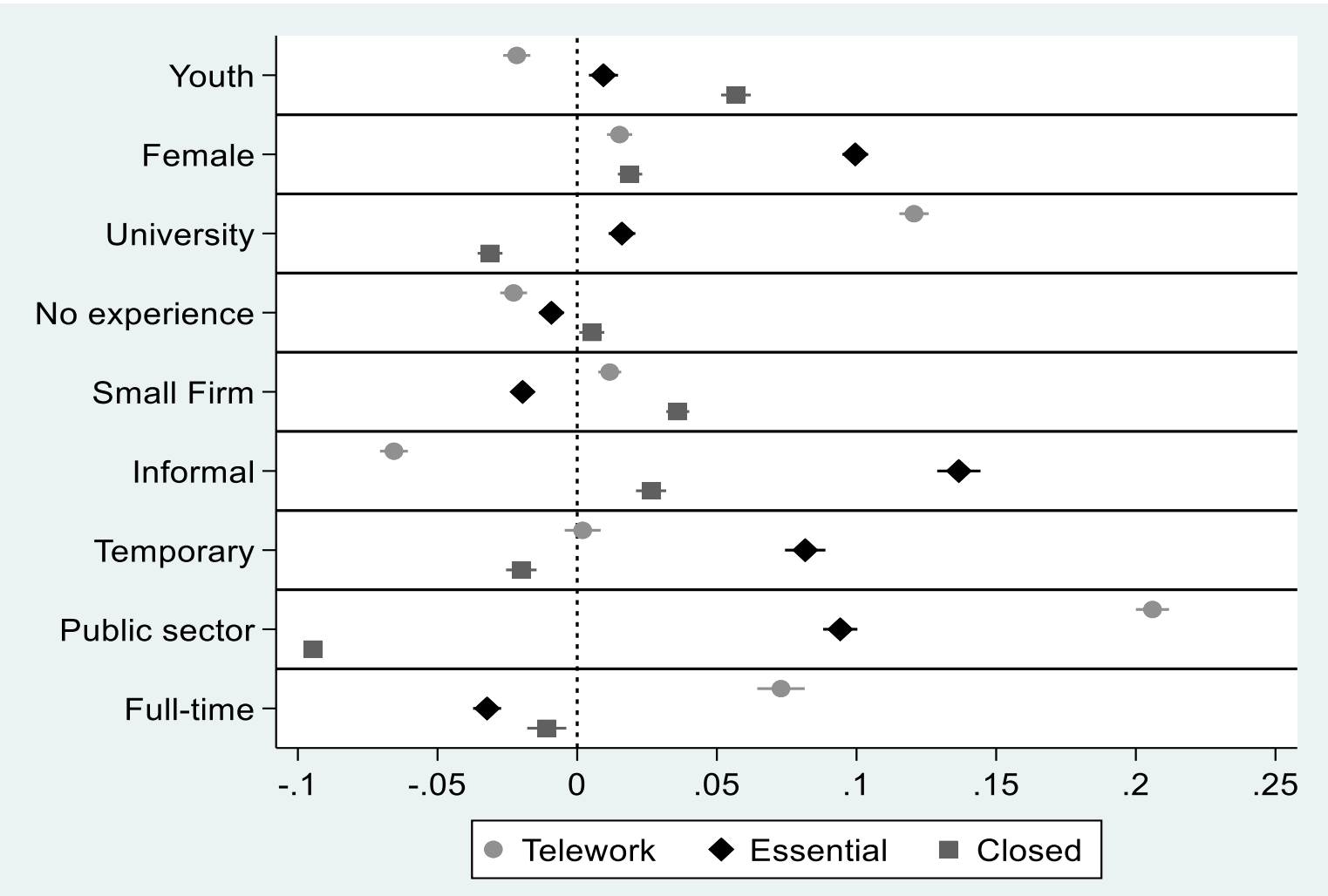

Notes: Based on the model is estimated using margins command after using zero-one inflated beta regression. dy/dx is the discrete change from the base level with $95 \%$ confidence interval levels.

These results can be helpful for designing targeted policies, especially if social distancing policies remain in place for long periods of time, which can generate major wage losses for 
employees in certain types of economic activities. Instead of simply focusing on the ability to work from home, non-essential and low teleworkable as well as closed jobs need to be taken into account to adequately protect workers during lockdown. For example, as an occupation managers have relatively higher ability to work from home, but the risks of managers in hospitality industry versus education are quite distinct as the former industry operates at extremely low capacity because of containment measures. Given that there are several common individual level factors affecting the PWI negatively or positively, policies can be more effectively targeted if they pay attention to the industrial-occupational differences rather than worker groups. The industrial-occupational structure of Turkey is highly comparable to other upper middle income countries ${ }^{8}$, and hence we argue that our findings can be relevant for these countries too, and PWI can guide the policy makers to decide about which economic activities to restrict and to develop safety nets for workers in such jobs.

\subsection{Distributional Consequences of Lockdown Policies}

A positive relationship between ability to work from home and wages is discovered in the existing studies, which led the researchers to argue for negative distributional consequences in labor market (Perugini and Vladisavljevic, 2020; Palamino et al., 2020). Since workers who have higher teleworkability are, at the same time, employed in high paying jobs, the influence of the lockdown on them would be relatively smaller compared to other working groups. However, as we discussed in the previous section, not only teleworkable jobs but also essential ones are maintained during the pandemic. In addition, there are major overlaps between teleworkable jobs

\footnotetext{
${ }^{8}$ Table A4 in the Appendix presents sectoral employment shares of Turkey and few selected economies at similar GDP per capita.
} 
and closed economic activities in terms of wage distribution. Figure A2 in the Appendix shows the deciles of yearly wages across three categories of jobs; highly teleworkable ${ }^{9}$, essential and closed. While low paying occupations are more frequent among the essential economic activities, this is not the case for closed sectors. Highly teleworkable and closed sectors are quite similar in terms of share of wages at the upper end of the distribution. Thus, distributional consequences of lockdown are less clear when PWI is considered rather than merely focusing on teleworking.

Figure 2 compares the wage inequality after 1 month, 3 months and 6 months lockdown to the pre-pandemic levels. New wages are computed by taking PWI of each individual in the labor market. It is clear that all three measures of inequality go up after social distancing and other containment policies the government implements. The changes in distribution of yearly wages can also be seen from the density plots exhibited in Figure A3 in the Appendix. Gini coefficient in the Turkish labor market before the lockdown was around 0.297 which rose to $0.303,0.32$ and 0.365 in each scenario. Even though these increases are small in absolute terms, in relative terms, the rise in wage inequality amounts to nearly $23 \%$ after 6 months of lockdown even with the previously closed sectors operating at $90 \%$ capacity. The deterioration in wage inequality by Gini coefficient is merely $2 \%$ after 1 month of full lockdown and $7.6 \%$ after 3 months of partial lockdown. Similarly, GE indices of wage inequality also rise after social distancing and because the indices are more sensitive to the simulated wage losses, the relative changes are higher than the Gini coefficient, especially for longer scenarios. GE(0) increases by $3 \%, 12 \%$ and $42 \%$ under 1 month, 3 months and 6 months duration of containment whereas the changes in $\operatorname{GE}(1)$ is around $3.5 \%, 14 \%$ and $45 \%$ for the same periods. These findings suggest that the lengthier the

\footnotetext{
${ }^{9}$ Highly teleworkable is defined as occupations that have ability to work from home scores above the weighted average of the country score.
} 
containment policies the higher the negative effects are on the labor market. Hence, a stricter and shorter lockdown is preferable from a distributional point of view.

Figure 2. Wage Inequality under Different Lockdown Scenarios

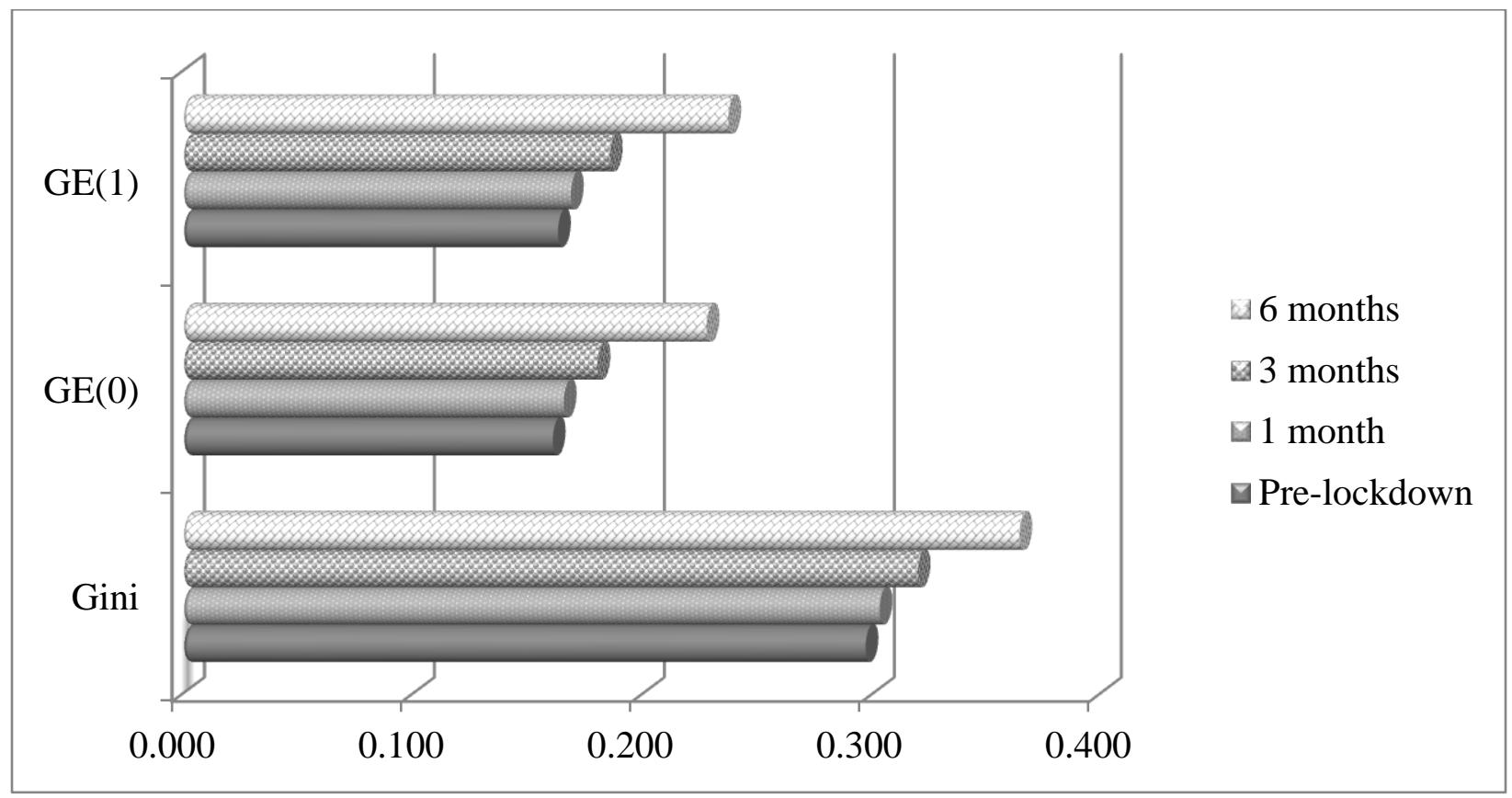

Lastly we exhibit the results for between and within group inequalities across three types of economic activity; teleworkable, essential and closed. As can be observed from Table X, within group wage dispersion is mainly responsible for the overall inequality both in our baseline estimations and under different scenarios. For example, approximately $97 \%$ of the wage inequality can be attributed to the distributional skewness within each subgroup by both GE indices before lockdown. Even though this ratio continues to be very high after the implementation of social distancing and the associated changes in the labor markets, the between group component of wage inequality is going up. After 6 months of lockdown, between group inequalities explain more than $5 \%$ of the overall dispersion as opposed to $3 \%$ of the baseline 
model. These figures highlight the distributional issues that can be experienced across different categories of jobs if containment policies are prolonged. As social distancing goes on and its labor market impacts are extended, the workers in essential, closed and teleworkable jobs face quite distinct trajectories of wage loss, and the variation across groups become more noticeable. Once again, our findings suggest that shorter and stricter lockdown measures could be more beneficial from the distributive perspective and can avoid large scale increases in wage dispersion, which can have socially negative consequences.

Table 3. Wage Inequality Between and Within Subgroups

\begin{tabular}{|c|c|c|c|c|c|}
\hline & GE(0) & Within & $\%$ & Between & $\%$ \\
\hline Baseline & 0.161 & 0.157 & 97.30 & 0.004 & 2.70 \\
\hline 1 Month & 0.166 & 0.161 & 96.93 & 0.005 & 3.07 \\
\hline 3 Months & 0.181 & 0.174 & 96.09 & 0.007 & 3.91 \\
\hline \multirow[t]{2}{*}{6 Months } & 0.228 & 0.215 & 94.24 & 0.013 & 5.76 \\
\hline & GE(1) & Within & $\%$ & Between & $\%$ \\
\hline Baseline & 0.164 & 0.160 & 97.55 & 0.004 & 2.45 \\
\hline 1 Month & 0.169 & 0.165 & 97.28 & 1.004 & 2.72 \\
\hline 3 Months & 0.186 & 0.180 & 96.60 & 2.004 & 3.40 \\
\hline 6 Months & 0.238 & 0.225 & 94.75 & 3.004 & 5.25 \\
\hline
\end{tabular}

Notes: Based on inequality decompositions by subgroups of economic activity 


\section{Conclusion}

Confinement measures and workplace shutdowns after the spread of Covid-19 in numerous countries affected the labor markets significantly. In this paper we examine the distributional consequences of pandemic using data from Turkish labor market. Although, there are various studies looking at wage inequality and poverty effects in the literature, these are focusing on the US and Europe. To this end, we developed possibility to work index by taking the ability to work from home and industrial restrictions into account. Our findings indicate that PWI is notably different than ability to work from home. Thus, PWI can more accurately capture the Covid-19 related labor market risks and be useful for the public authorities to design better targeted social policies. Moreover, among the closed economic activities there are both high paid and low paid jobs with equal risk of wage losses during the lockdown. Hence the distributional implications of temporary workplace closures are not unambiguous. In the paper, we demonstrated a rise in the wage inequality but the increase in earnings dispersion gets much larger as the confinement policies are extended. To prevent large scale deterioration in wage distribution and long term socio-economic problems that can arise, governments can benefit from implementing shorter and rigorous lockdowns.

While our findings hint at important developments that are observed after the pandemic, there are several weaknesses. First of all, we only examine the economic risks which are unevenly allocated across industries and ignore the health risks that workers in essential jobs are facing. Health inequalities can be equally alarming and might produce long term hurdles socioeconomically. Given the lack of social distancing in some of these economic activities, people would suffer from infections even if their wages are unaffected. Secondly, we mainly consider 
supply shocks but clearly the demand is contracting for a number of goods and services. The demand effects on wage losses and inequality can be substantial depending on the extent and duration of the contraction. Due to the lack of data on the relevant aspects of the Turkish economy, we are unable to incorporate the demand side into our analysis. Nevertheless, the addition of demand shocks is expected to aggravate the wage loss risks and impair the distribution of earnings further. Hence, governments would need to develop safety nets and social policies to mitigate the negative labor market impacts. 


\section{References}

Barrot, J-N., Grassi, B. and Sauvagnat, J. (2020) "Sectoral effects of social distancing". Available at: http://www.igier.unibocconi.it/files/BGS_WP_20200404_(1).pdf.

Boeri, T., Caiumi, A. and Paccagnella, M. (2020) "Mitigating the Work-Safety Trade-off". Covid Economics: Vetted and real-time papers, 2, 60-67.

Brunori, P., Maitino, M.L., Ravagli, L. and Sciclone, N. (2020) "Distant and unequal. Lockdown and Inequalities in Italy". Available at: http://www.unicaldine.it/research/BMRS_2020.pdf

Bsg.ox.ac.uk (2020) “Government Response Tracker”. Available at: https://www.bsg.ox.ac.uk/research/research-projects/coronavirus-government-response-tracker

Cho, S.J. and Winters, J. (2020) "The Distributional Impacts of Early Employment Losses from COVID-19”. IZA Discussion Paper, No. 13266.

del Rio-Chanona, R., Mealy, P., Pichler, A., Lafond, F. and Farmer, D. (2020) "Supply and demand shocks in the COVID-19 pandemic: An industry and occupation perspective". Available at: https://arxiv.org/abs/2004.06759.

Delaporte, I. and Pena, W. (2020) "Working From Home Under COVID-19: Who Is Affected? Evidence From Latin American and Caribbean Countries". GLO Discussion Paper Series, No. 528.

Dingel, J. I and Neiman, B. (2020) "How many jobs can be done at home?". Covid Economics: Vetted and Real-Time Papers, 1, 16-24.

Foster, J.E. and Shneyerov, A.A. (2000) "Path Independent Inequality Measures". Journal of Economic Theory, 91(2), 199-222. 
Gottlieb, C., Grobovsek, J. and Poschke, (2020) "Working from home across countries". Cahier Working Papers, No. 07-2020.

Hatayama, M., Viollaz, M. and Winkler, H. (2020) “Jobs' Amenability to Working from Home: Evidence from Skills Surveys for 53 Countries". World Bank Policy Research Working Papers, No. 9241.

Montenovo, L., Jiang, X., Rojas, F.L. Schmutte, I., Simon, I.K., Weinberg, B. and Wing, C. (2020) "Determinants of disparities in covid-19 job losses" NBER Working Papers, No. 27132.

Ospina, R. and Ferrari S.L.P. (2012) “A general class of zero-or-one inflated beta regression models". Computational Statistics and Data Analysis, 56, 1609-1623.

Palomino, J.C., Rodriguez, J.G. and Sebastian, R. (2020) "Wage inequality and poverty effects of lockdown and social distancing in Europe". Available at: https://www.inet.ox.ac.uk/publications/no-2020-13-wage-inequality-and-poverty-effects-oflockdown-and-social-distancing-in-europe/.

Perugini, C. and Vladisavljevic, M. (2020) Social Stability Challenged: Pandemics, Inequality and Policy Responses. IZA Discussion Paper, No. 13249.

Saltiel, F. (2020) "Who can work from home in developing countries". Covid Economics, 7, 104-118. 


\section{Appendix}

Table A1. Teleworking and Lockdown in Selected Countries

\begin{tabular}{lcc}
\hline & Teleworkable Jobs & $\begin{array}{c}\text { Stringency of Workplace } \\
\text { Closures }\end{array}$ \\
\hline Argentina & 0.31 & 2.62 \\
Brazil & 0.28 & 2.97 \\
Chile & 0.26 & 2.29 \\
Mexico & 0.24 & 2.61 \\
Panama & 0.25 & 2.65 \\
Turkey & 0.25 & 2.00 \\
Russian Federation & 0.34 & 2.53 \\
South Africa & 0.28 & 2.21 \\
Uruguay & 0.29 & 1.00 \\
\hline
\end{tabular}

Notes: Share of teleworkable jobs is calculated at the ISCO-08 2-digit level weighted by the employment shares in each occupation. Stringency of workplace closures is the unweighted average of scores between $15^{\text {th }}$ of March and $1^{\text {st }}$ of June. The country has a score of 1 if closing or work from home is recommended; score of 2 if closing or work from home is required for some sectors or categories of workers; and a score of 3 if closing or work from home is required for all but essential workplaces. The data is obtained from https://www.bsg.ox.ac.uk/research/researchprojects/coronavirus-government-response-tracker. 
Table A2. Classification of Essential, Closed and Teleworkable Economic Activities

\begin{tabular}{|c|c|c|c|c|}
\hline $\begin{array}{l}\text { NACE } \\
\text { Code }\end{array}$ & Title & Essential & Closed & Teleworkable \\
\hline 1 & $\begin{array}{l}\text { Crop and animal production, hunting and } \\
\text { related service activities }\end{array}$ & 1 & 0 & 0 \\
\hline 2 & Forestry and logging & 0 & 0 & 1 \\
\hline 3 & Fishing and aquaculture & 1 & 0 & 0 \\
\hline 5 & Mining of coal and lignite & 0 & 0 & 1 \\
\hline 6 & Extraction of crude petroleum and natural gas & 1 & 0 & 0 \\
\hline 7 & Mining of metal ores & 0 & 0 & 1 \\
\hline 8 & Other mining and quarrying & 0 & 0 & 1 \\
\hline 9 & Mining support service activities & 0 & 0 & 1 \\
\hline 10 & Manufacture of food products & 1 & 0 & 0 \\
\hline 11 & Manufacture of beverages & 1 & 0 & 0 \\
\hline 12 & Manufacture of tobacco products & 0 & 0 & 1 \\
\hline 13 & Manufacture of textiles & 0 & 0 & 1 \\
\hline 14 & Manufacture of wearing apparel & 0 & 0 & 1 \\
\hline 15 & Manufacture of leather and related products & 0 & 0 & 1 \\
\hline 16 & $\begin{array}{l}\text { Manufacture of wood and of products of wood } \\
\text { and cork, except furniture; manufacture of } \\
\text { articles of straw and plaiting materials }\end{array}$ & 0 & 0 & 1 \\
\hline 17 & Manufacture of paper and paper products & 0 & 0 & 1 \\
\hline 18 & Printing and reproduction of recorded media & 1 & 0 & 0 \\
\hline 19 & $\begin{array}{l}\text { Manufacture of coke and refined petroleum } \\
\text { products }\end{array}$ & 1 & 0 & 0 \\
\hline 20 & $\begin{array}{l}\text { Manufacture of chemicals and chemical } \\
\text { products }\end{array}$ & 0 & 0 & 1 \\
\hline 21 & $\begin{array}{l}\text { Manufacture of basic pharmaceutical products } \\
\text { and pharmaceutical preparations }\end{array}$ & 1 & 0 & 0 \\
\hline 22 & Manufacture of rubber and plastic products & 0 & 0 & 1 \\
\hline 23 & $\begin{array}{l}\text { Manufacture of other non-metallic mineral } \\
\text { products }\end{array}$ & 0 & 0 & 1 \\
\hline 24 & Manufacture of basic metals & 0 & 0 & 1 \\
\hline 25 & $\begin{array}{l}\text { Manufacture of fabricated metal products, } \\
\text { except machinery and equipment }\end{array}$ & 0 & 0 & 1 \\
\hline 26 & $\begin{array}{l}\text { Manufacture of computer, electronic and optical } \\
\text { products }\end{array}$ & 0 & 0 & 1 \\
\hline 27 & Manufacture of electrical equipment & 0 & 0 & 1 \\
\hline 28 & Manufacture of machinery and equipment n.e.c. & 0 & 0 & 1 \\
\hline 29 & $\begin{array}{l}\text { Manufacture of motor vehicles, trailers and } \\
\text { semi-trailers }\end{array}$ & 0 & 0 & 1 \\
\hline 30 & Manufacture of other transport equipment & 0 & 0 & 1 \\
\hline 31 & Manufacture of furniture & 0 & 0 & 1 \\
\hline 32 & Other manufacturing & 0 & 0 & 1 \\
\hline
\end{tabular}




\begin{tabular}{|c|c|c|c|c|}
\hline 33 & $\begin{array}{l}\text { Repair and installation of machinery and } \\
\text { equipment }\end{array}$ & 0 & 0 & 1 \\
\hline 35 & $\begin{array}{l}\text { Electricity, gas, steam and air conditioning } \\
\text { supply }\end{array}$ & 1 & 0 & 0 \\
\hline 36 & Water collection, treatment and supply & 1 & 0 & 0 \\
\hline 37 & Sewerage & 1 & 0 & 0 \\
\hline 38 & $\begin{array}{l}\text { Waste collection, treatment and disposal } \\
\text { activities; materials recovery }\end{array}$ & 1 & 0 & 0 \\
\hline 39 & $\begin{array}{l}\text { Remediation activities and other waste } \\
\text { management services }\end{array}$ & 1 & 0 & 0 \\
\hline 41 & Construction of buildings & 0 & 0 & 1 \\
\hline 42 & Civil engineering & 0 & 0 & 1 \\
\hline 43 & Specialised construction activities & 0 & 0 & 1 \\
\hline 45 & $\begin{array}{l}\text { Wholesale and retail trade and repair of motor } \\
\text { vehicles and motorcycles }\end{array}$ & 0 & 0 & 1 \\
\hline 46 & $\begin{array}{l}\text { Wholesale trade, except of motor vehicles and } \\
\text { motorcycles }\end{array}$ & 0 & 0 & 1 \\
\hline 47 & $\begin{array}{l}\text { Retail trade, except of motor vehicles and } \\
\text { motorcycles }\end{array}$ & 0 & 0 & 1 \\
\hline 49 & Land transport and transport via pipelines & 1 & 0 & 0 \\
\hline 50 & Water transport & 1 & 0 & 0 \\
\hline 51 & Air transport & 0 & 0 & 1 \\
\hline 52 & $\begin{array}{l}\text { Warehousing and support activities for } \\
\text { transportation }\end{array}$ & 1 & 0 & 0 \\
\hline 53 & Postal and courier activities & 1 & 0 & 0 \\
\hline 55 & Accommodation & 0 & 1 & 0 \\
\hline 56 & Food and beverage service activities & 0 & 1 & 0 \\
\hline 58 & Publishing activities & 1 & 0 & 0 \\
\hline 59 & $\begin{array}{l}\text { Motion picture, video and television } \\
\text { programme production, sound recording and } \\
\text { music publishing activities }\end{array}$ & 0 & 0 & 1 \\
\hline 60 & Programming and broadcasting activities & 1 & 0 & 0 \\
\hline 61 & Telecommunications & 1 & 0 & 0 \\
\hline 62 & $\begin{array}{l}\text { Computer programming, consultancy and } \\
\text { related activities }\end{array}$ & 0 & 0 & 1 \\
\hline 63 & Information service activities & 0 & 0 & 1 \\
\hline 64 & $\begin{array}{l}\text { Financial service activities, except insurance } \\
\text { and pension funding }\end{array}$ & 0 & 0 & 1 \\
\hline 65 & $\begin{array}{l}\text { Insurance, reinsurance and pension funding, } \\
\text { except compulsory social security }\end{array}$ & 0 & 0 & 1 \\
\hline 66 & $\begin{array}{l}\text { Activities auxiliary to financial services and } \\
\text { insurance activities }\end{array}$ & 0 & 0 & 1 \\
\hline 68 & Real estate activities & 0 & 1 & 0 \\
\hline 69 & Legal and accounting activities & 0 & 0 & 1 \\
\hline 70 & Activities of head offices; management & 0 & 0 & 1 \\
\hline
\end{tabular}




\begin{tabular}{|c|c|c|c|c|}
\hline & consultancy activities & & & \\
\hline 71 & $\begin{array}{l}\text { Architectural and engineering activities; } \\
\text { technical testing and analysis }\end{array}$ & 0 & 0 & 1 \\
\hline 72 & Scientific research and development & 0 & 0 & 1 \\
\hline 73 & Advertising and market research & 0 & 0 & 1 \\
\hline 74 & $\begin{array}{l}\text { Other professional, scientific and technical } \\
\text { activities }\end{array}$ & 0 & 0 & 1 \\
\hline 75 & Veterinary activities & 1 & 0 & 0 \\
\hline 77 & Rental and leasing activities & 0 & 0 & 1 \\
\hline 78 & Employment activities & 0 & 0 & 1 \\
\hline 79 & $\begin{array}{l}\text { Travel agency, tour operator and other } \\
\text { reservation service and related activities }\end{array}$ & 0 & 1 & 0 \\
\hline 80 & Security and investigation activities & 0 & 0 & 1 \\
\hline 81 & Services to buildings and landscape activities & 0 & 0 & 1 \\
\hline 82 & $\begin{array}{l}\text { Office administrative, office support and other } \\
\text { business support activities }\end{array}$ & 0 & 1 & 0 \\
\hline 84 & $\begin{array}{l}\text { Public administration and defence; compulsory } \\
\text { social security }\end{array}$ & 0 & 0 & 1 \\
\hline 85 & Education & 0 & 0 & 1 \\
\hline 86 & Human health activities & 1 & 0 & 0 \\
\hline 87 & Residential care activities & 1 & 0 & 0 \\
\hline 88 & Social work activities without accommodation & 1 & 0 & 0 \\
\hline 90 & Creative, arts and entertainment activities & 0 & 1 & 0 \\
\hline 91 & $\begin{array}{l}\text { Libraries, archives, museums and other cultural } \\
\text { activities }\end{array}$ & 0 & 1 & 0 \\
\hline 92 & Gambling and betting activities & 0 & 1 & 0 \\
\hline 93 & $\begin{array}{l}\text { Sports activities and amusement and recreation } \\
\text { activities }\end{array}$ & 0 & 1 & 0 \\
\hline 94 & Activities of membership organisations & 0 & 0 & 1 \\
\hline 95 & $\begin{array}{l}\text { Repair of computers and personal and } \\
\text { household goods }\end{array}$ & 0 & 0 & 1 \\
\hline 96 & Other personal service activities & 0 & 1 & 0 \\
\hline 97 & $\begin{array}{l}\text { Activities of households as employers of } \\
\text { domestic personnel }\end{array}$ & 0 & 0 & 1 \\
\hline 98 & $\begin{array}{l}\text { Undifferentiated goods- and services-producing } \\
\text { activities of private households for own use }\end{array}$ & 0 & 1 & 0 \\
\hline 99 & $\begin{array}{l}\text { Activities of extraterritorial organisations and } \\
\text { bodies }\end{array}$ & 0 & 0 & 1 \\
\hline
\end{tabular}

Notes: Economic activities are coded according to the changes and regulations published in the Official Gazette and circulars of Ministry of Interior; https://www.resmigazete.gov.tr/eskiler/2020/05/20200529.pdf; https://www.resmigazete.gov.tr/eskiler/2020/03/20200327.pdf; https://www.mevzuat.gov.tr/MevzuatMetin/1.5.7244.pdf. 
Table A3. Logit Estimations across Categories of Economic Activity

\begin{tabular}{|c|c|c|c|c|c|c|}
\hline & Telework & & Essential & & Closed & \\
\hline & Coefficient & SE & Coefficient & SE & Coefficient & SE \\
\hline Youth & $-0.40^{* *}$ & 0.02 & $0.11 * *$ & 0.03 & $0.59 * *$ & 0.03 \\
\hline Female & $0.44 * *$ & 0.02 & $1.10 * *$ & 0.02 & $0.20 * *$ & 0.02 \\
\hline University & $0.26 * *$ & 0.02 & $0.21 * *$ & 0.04 & $-0.42 * *$ & 0.03 \\
\hline No experience & $-0.10 * *$ & 0.02 & $-0.13 * *$ & 0.03 & $-0.10 * *$ & 0.03 \\
\hline Small firm & $-0.26 * *$ & 0.02 & $-0.27 * *$ & 0.04 & $-0.41 * *$ & 0.02 \\
\hline Informal & $-0.65 * *$ & 0.02 & $1.27 * *$ & 0.03 & $0.30 * *$ & 0.03 \\
\hline Temporary & -0.02 & 0.02 & $0.80 * *$ & 0.03 & $-0.35^{* *}$ & 0.04 \\
\hline Full-time & $0.18 * *$ & 0.03 & $-0.43 * *$ & 0.04 & $-0.13 * *$ & 0.05 \\
\hline Public sector & $0.59 * *$ & 0.02 & $0.97 * *$ & 0.03 & $-1.81 * *$ & 0.05 \\
\hline Region & Yes & & Yes & & Yes & \\
\hline Constant & $-0.78 * *$ & 0.02 & $-3.75^{* *}$ & 0.04 & $-2.27 * *$ & 0.03 \\
\hline Number of obs & 104,097 & & 104,097 & & 104,097 & \\
\hline Wald chi2(20) & 5182.72 & & 6593.95 & & 4480.51 & \\
\hline Prob > chi 2 & 0.00 & & 0.00 & & 0.00 & \\
\hline
\end{tabular}

Notes: The models are estimated using logit regressions with robust standard errors. $* *$ and $*$ denote statistical significance at the .01 and .05 levels, respectively. 
Table A4. Employment Shares (ISIC Rev 4) in Selected Countries

\begin{tabular}{|c|c|c|c|c|c|c|c|c|}
\hline & Argentina & Brazil & Chile & Mexico & Panama & $\begin{array}{l}\text { Russian } \\
\text { Federation }\end{array}$ & Turkey & Uruguay \\
\hline A. & 0.06 & 9.07 & 8.98 & 12.38 & 14.41 & 5.83 & 17.49 & 8.41 \\
\hline B. & 0.04 & 0.45 & 2.68 & 0.37 & 0.39 & 2.30 & 0.43 & 0.13 \\
\hline C. & 11.90 & 11.40 & 9.86 & 16.57 & 7.54 & 14.26 & 17.72 & 10.31 \\
\hline D. & 0.35 & 0.24 & 0.51 & 0.17 & 0.27 & 2.61 & 0.40 & 0.48 \\
\hline E. & 0.45 & 0.70 & 0.63 & 0.45 & 0.52 & 0.72 & 0.57 & 0.68 \\
\hline F. & 9.04 & 7.19 & 8.57 & 7.81 & 9.00 & 6.90 & 5.33 & 7.23 \\
\hline G. & 18.14 & 18.96 & 18.64 & 21.25 & 18.19 & 15.57 & 13.48 & 17.93 \\
\hline H. & 5.32 & 5.20 & 6.83 & 4.43 & 7.53 & 8.78 & 4.32 & 4.97 \\
\hline I. & 3.85 & 5.90 & 4.26 & 7.98 & 5.28 & 2.63 & 5.85 & 3.95 \\
\hline $\mathrm{J}$. & 2.28 & 1.37 & 1.65 & 0.72 & 1.43 & 1.80 & 0.81 & 2.21 \\
\hline K. & 2.11 & 1.37 & 1.89 & 1.01 & 2.42 & 2.26 & 1.02 & 1.64 \\
\hline L. & 0.68 & 0.63 & 0.92 & 0.39 & 0.75 & 1.71 & 1.02 & 0.58 \\
\hline $\mathrm{M}$ & 4.16 & 3.46 & 3.04 & 2.74 & 2.35 & 3.27 & 3.05 & 3.89 \\
\hline N. & 3.95 & 4.45 & 2.64 & 2.71 & 3.73 & 2.48 & 3.31 & 4.50 \\
\hline O. & 8.15 & 5.38 & 5.72 & 4.23 & 6.13 & 6.98 & 6.68 & 6.47 \\
\hline P. & 8.26 & 6.97 & 8.86 & 4.81 & 5.50 & 9.51 & 6.20 & 6.36 \\
\hline Q. & 6.30 & 5.10 & 5.96 & 2.83 & 4.77 & 7.91 & 5.13 & 8.29 \\
\hline R. & 2.00 & 1.08 & 1.31 & 0.87 & 1.01 & 2.01 & 0.59 & 1.87 \\
\hline S. & 3.87 & 4.28 & 3.05 & 3.20 & 4.09 & 2.44 & 2.54 & 3.20 \\
\hline $\mathrm{T}$. & 7.69 & 6.75 & 3.99 & 4.35 & 4.62 & 0.02 & 0.60 & 6.79 \\
\hline $\mathrm{U}$. & 1.16 & 0.01 & 0.01 & 0.00 & 0.10 & 0.01 & 0.02 & 0.10 \\
\hline \multicolumn{9}{|c|}{$\begin{array}{l}\text { A. Agriculture; forestry and fishing; B. Mining and quarrying; C. Manufacturing; D. Electricity; gas, steam and air } \\
\text { conditioning supply; E. Water supply; sewerage, waste management and remediation activities; F. Construction; G. } \\
\text { Wholesale and retail trade; repair of motor vehicles and motorcycles; H. Transportation and storage; I. } \\
\text { Accommodation and food service activities; J. Information and communication; K. Financial and insurance } \\
\text { activities; L. Real estate activities; M. Professional, scientific and technical activities; N. Administrative and support } \\
\text { service activities; O. Public administration and defence; compulsory social security; P. Education; Q. Human health } \\
\text { and social work activities; R. Arts, entertainment and recreation; S. Other service activities; T. Activities of } \\
\text { households as employers; undifferentiated goods- and services-producing activities of households for own use; U. } \\
\text { Activities of extraterritorial organizations and bodies }\end{array}$} \\
\hline
\end{tabular}


Figure A1. Distribution of PWI

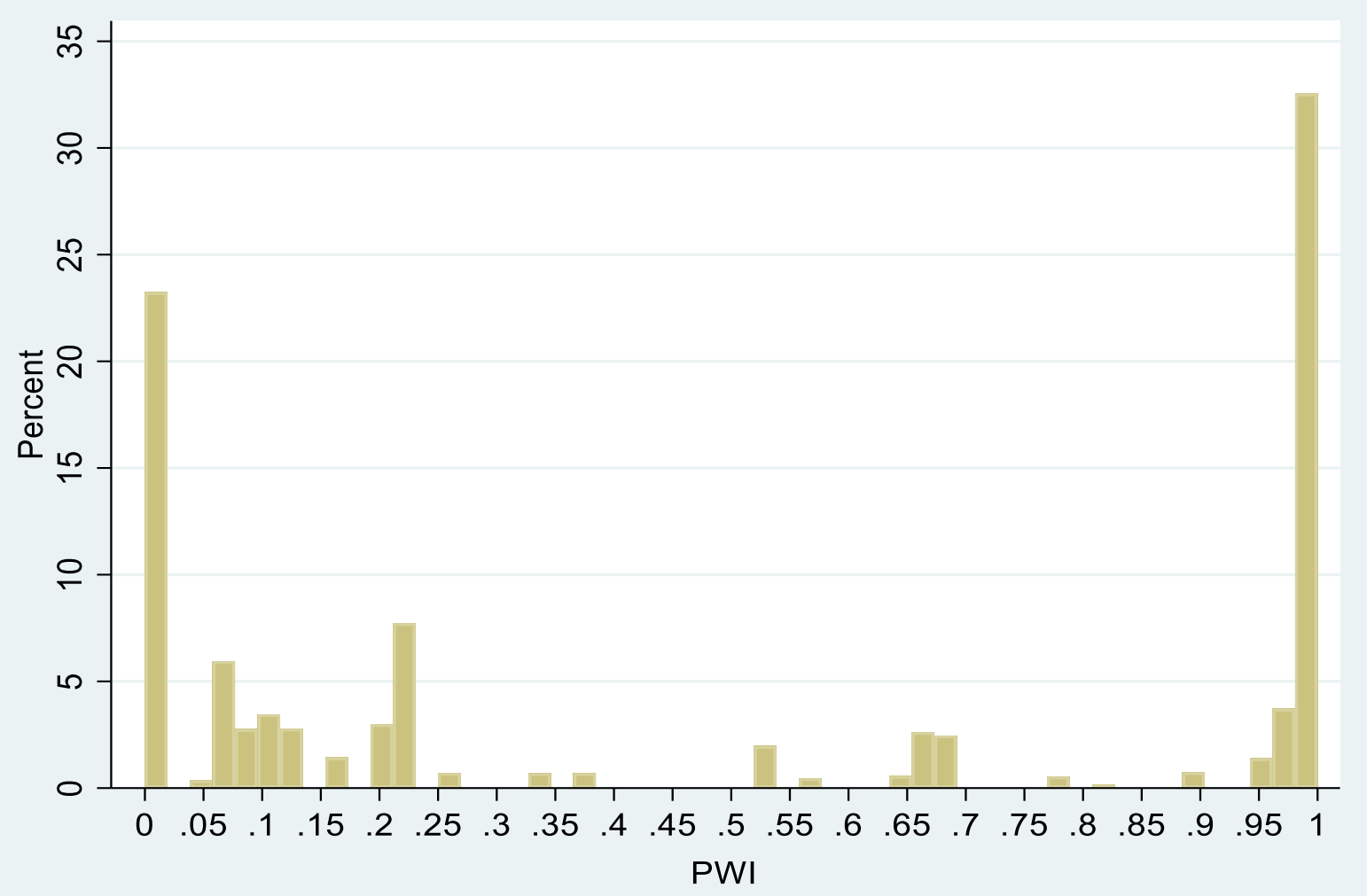


Figure A2. Wage Distribution by Deciles across Categories of Economic Activity

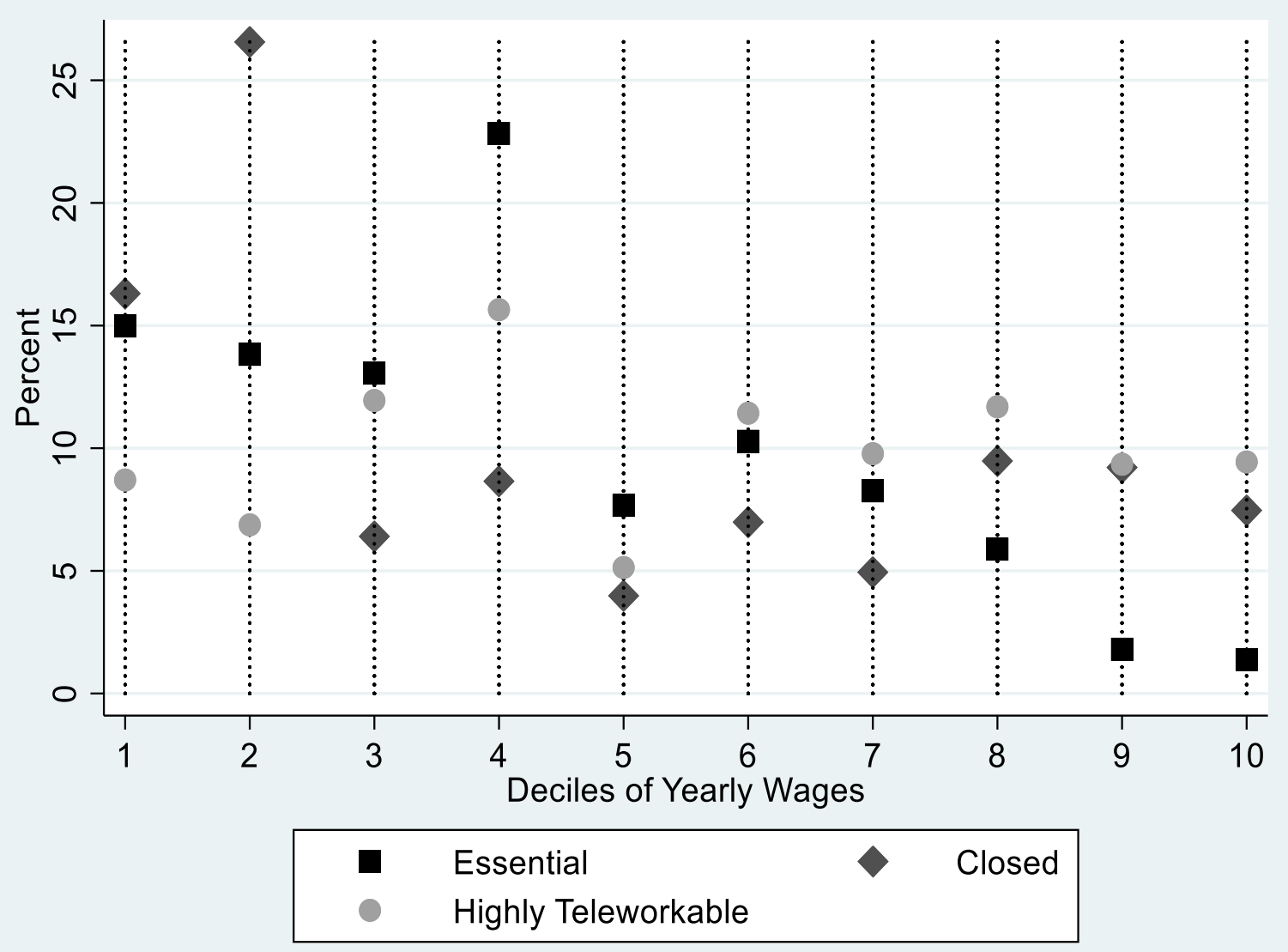


Figure A3. Density Plots for Yearly Wages

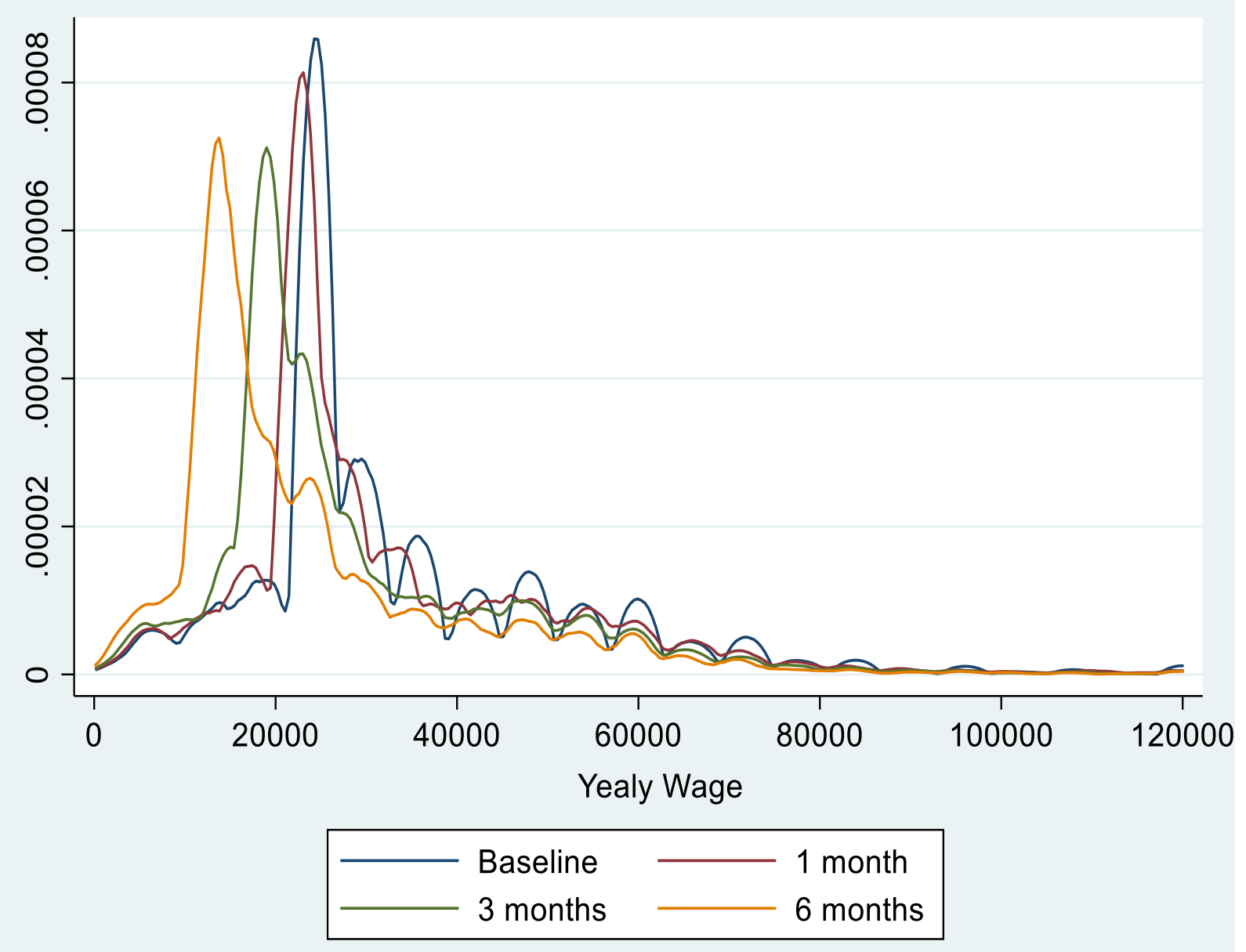

